\title{
Treatment of equine endometritis with intrauterine irrigations of ceftiofur sodium: a comparison with mares treated in a similar manner with a mixture of sodium benzylpenicillin, neomycin sulphate, polymixin B sulphate and furaltadone hydrochloride
}

\author{
S. W. Ricketts \\ Rossdale and Partners, Beaufort Cottage Stables, Newmarket, England
}

\begin{abstract}
Summary
1462 mares were treated for acute endometritis, of which 1207 were treated with intrauterine irrigations of $3 \mathrm{~g}$ sodium benzylpenicillin, $1 \mathrm{~g}$ neomycin sulphate, 40,000 iu polymixin B sulphate and $600 \mathrm{mg}$ furaltadone hydrochloride dissolved in $100 \mathrm{ml}$ sterile water for injection and 255 were treated with intrauterine irrigations of $1 \mathrm{~g}$ ceftiofur sodium (Excenel, Upjohn) dissolved in $100 \mathrm{ml}$ sterile water for injection. 40 mares who were treated by once daily intrauterine irrigation with either penicillin, neomycin, polymixin and furaltadone mixture (24) or ceftiofur sodium (16), for three consecutive days, were selected for more detailed pre- and post-treatment endometrial cytological and bacteriological analysis. The results suggest that treatment with ceftiofur sodium is as safe and at least as efficacious in the treatment of acute endometritis as treatment with penicillin, neomycin, polymixin and furaltadone mixture.
\end{abstract}

keywords: $\quad$ Equine Endometritis, Ceftiofur sodium

\begin{abstract}
Behandlung der equinen Endometritis mit intrauterinen Spülungen von Ceftiofur-Natrium: Ein Vergleich mit Stuten, die auf gleiche Weise mit einer Mischung aus Natrium-Benzylpenicillin, Neomycin-Sulfat, Polymyxin-B-Sulfat und Furaltadon-Hydrochlorid behandelt wurden

1462 Stuten wurden aufgrund einer akuten Endometritis mittels zwei verschiedener intrauteriner Lösungen therapiert. 1207 Tiere erhielten eine Mischung, die aufgrund langjähriger Erfahrungen in dieser Praxis üblich ist (3g Natrium-Benzylpenicillin, $1 \mathrm{~g}$ Neomycin-Sulfat, $40000 \mathrm{IE}$ Polymyxin-B-Sulfat und $600 \mathrm{mg}$ Furaltadon-Hydrochlorid, gelöst in $100 \mathrm{ml}$ sterilem Wasser pro inject.). 255 Patientinnen wurden mit $1 \mathrm{~g}$ Ceftiofur-Natrium (Excenel, Upjohn), gelöst in $100 \mathrm{ml}$ sterilem Wasser pro inject., behandelt. 40 Stuten beider Therapiegruppen (tägliche Uterusspülung an drei aufeinanderfolgenden Tagen; $n=24$ : Penicillin-Neomycin-Polymyxin-Furaltadon-Mischung; $n=16$ : Ceftiofur-Natrium) wurden für weitere detailliertere Untersuchungen ausgewählt. Vor und nach der Behandlung erfolgten zytologische und bakteriologische Befunderhebungen. Die Ergebnisse zeigen, daß eine Behandlung mit Ceftiofur-Natrum genauso sicher und zuverlässig zur Endometritis-Therapie eingesetzt werden kann, wie die herkömmliche Therapie mit einer Mischung aus Penicillin, Neomycin, Polymyxin und Furaltadon.
\end{abstract}

Schlüsselwörter: Equine Endometritis, Ceftiofur-Natrium

Introduction

Transient acute endometritis, associated with uterine contamination with the mixed aerobic and anaerobic bacterial flora which normally colonises equine external genitalia, is an inevitable sequal to natural coitus in mares (Peterson et al., 1969; Hughes and Loy, 1975; Kenney et al., 1975; Ricketts \& Mackintosh, 1987; Ricketts et al., 1993). Persistent acute endometritis can result where genital structural or functional abnormality occurs, leading to subfertility (Rossdale and Ricketts, 1980). Satisfactory treatment of persistent acute endometritis requires repeated intrauterine irrigations with antibiotic solutions to which the pathogens involved are sensitive and correction, where possible, of predisposing abnormalities. 'First choice' intrauterine antibiotic treatments should be deliberately broad spectrum to successfully treat all components of the mixed aerobic (most commonly beta-haemolytic streptococci, Escherichia coli and Staphylococcus aureus) and anaerobic (most commonly Bacteroides fragilis) infections that frequently occur (Ricketts and Mackintosh, 1987) and should be water-soluble, completely absorbable and non-irritant, so as not to encourage colonisation with more resistant organisms such as Pseudomonas spp. or fungi (Ricketts, 1987; Ricketts, 1995). 25 years experience in equine studfarm practice has shown that an aqueous solution of sodium benzylpenicillin, neomycin sulphate, polymixin B sulphate and furaltadone hydrochloride fulfils all these criteria. Recently, ceftiofur sodium, a water soluble beta-lactamase resistant, broad spectrum, bactericidal antibiotic, with a 
recognised activity against Bacteroides fragilis, has been $\mathrm{li}$ censed for the treatment of respiratory infections in horses. Burmudez et al. (1995) treated 20 Venezuelan mares with intrauterine infusions of either 1 or $2 \mathrm{~g}$ ceftiofur sodium and concluded that it was non-irritant and that it improved the fertility of mares who were 'susceptible' to endometritis. The aim of this study was to repeat the Venezuelan study and to assess the efficacy and suitability of ceftiofur as an intrauterine treatment for acute endometritis in mares, by comparison with results of mares similarly treated with the penicillin, neomycin, polymixin and furaltadone mixture.

\section{Materials and methods}

Between 1st February and 31st July 1996, 1462 mares were treated for acute endometritis by clinicians at Rossdale and Partners. 1207 were treated with intrauterine irrigations with an aqueous solution of $3 \mathrm{~g}$ sodium benzy/penicillin, $1 \mathrm{~g}$ neomycin sulphate, 40,000 iu polymixin B sulphate and $600 \mathrm{mg}$ furaltadone hydrochloride and 255 with intrauterine irrigations with an aqueous solution of $1 \mathrm{~g}$ ceftiofur sodium (Excenel, Upjohn). From these 1462 mares, the results of 40 who were treated by once daily intrauterine irrigation with either the penicillin, neomycin, polymixin and furaltadone mixture (24 mares) or ceftiofur sodium (16 mares), for three consecutive days, were selected for more detailed analysis as they included the results of both pre- and posttreatment endometrial cytological and bacteriological examinations. None of these mares showed signs of pyometritis or uterine fluid accumulation on ultrasound examination and therefore more extensive treatment with large volume intrauterine sterile saline irrigations and intravenous oxytocin administrations were not indicated.

Non-guarded endometrial swab and smear samples were collected during early oestrus, via a sterile disposable vaginal speculum, processed and interpreted using methods used routinely in equine studfarm practice and described by Ricketts (1981), Mackintosh (1981), Wingfield Digby (1978), Wingfield Digby and Ricketts (1982), Ricketts and Mackintosh (1987) and Ricketts et al. (1993). Acute endometritis was diagnosed by the presence of $>0.5 \%$ polymorphonuclear leucocytes (pmns) in a stained endometrial smear sample, in the presence of adequate numbers of endometrial epithelial cells to confirm smear quality. Conversely, successful resolution of acute endometritis was diagnosed by $<0.5 \%$ pmns in a post-treatment endometrial smear sample. Aerobic and microaerophilic bacteriological cultures were performed on endometrial swab samples to screen for the potential primary equine venereal pathogens Taylorella equigenitalis, Klebsiella pneumoniae and Pseudomonas aeruginosa (Powell et al., 1978) and to identify aerobic bacteria responsible for cases of acute endometritis, diagnosed on cytological grounds. Anaerobic bacterial cultures were not performed.

The 40 mares selected for detailed study were treated with a three day course of once daily intrauterine irrigations, via a sterile disposable plastic insemination pipette, introduced manually per vaginam following hygienic preparation of the perineum. The treatment course was either three days of $3 \mathrm{~g}$ sodium benzylpenicillin, $1 \mathrm{~g}$ neomycin sulphate, 40,000 iu polymixin B sulphate and $600 \mathrm{mg}$ furaltadone hydrochloride dissolved in $100 \mathrm{ml}$ sterile water for injection or $1 \mathrm{~g}$ ceftiofur sodium dissolved in $100 \mathrm{ml}$ sterile water for injection. Treatment started on the day following initial endometrial swab and smear collection, i. e. during oestrus. These mares were not mated during that oestrus period. They were re-examined and follow-up endometrial swab and smear samples were collected, processed and interpreted at the start of their next oestrous period (Table 1 and 2).

Tab.1: Mares treated with 3 daily intrauterine irrigations with $3 \mathrm{~g}$ sodium benzylpenicillin, $1 \mathrm{~g}$ neomycin sulphate, 40,000 iu polymixin $\mathrm{B}$ sulphate and $600 \mathrm{mg}$ furaltadone hydrochloride dissolved in $100 \mathrm{ml}$ sterile water for injection.

Stuten, die 3 mal täglich mit einer intrauterinen Spülung (wäßrige Lösung aus Natrium-Benzylpenicillin, Neomycin-Sulphat, Polymyxin-B-Sulphat and Furaltadon-Hydrochlorid) behandelt wurden.

\begin{tabular}{|c|c|c|c|c|c|}
\hline \multirow[t]{2}{*}{ Mare } & \multicolumn{2}{|c|}{$\begin{array}{c}\text { Initial } \\
\text { examination }\end{array}$} & \multicolumn{2}{|c|}{$\begin{array}{l}\text { Follow-up } \\
\text { examination }\end{array}$} & \multirow[t]{2}{*}{ Fert } \\
\hline & pmns & $\begin{array}{l}\text { bacterial } \\
\text { growth }\end{array}$ & pmns & $\begin{array}{l}\text { bacterial } \\
\text { growth }\end{array}$ & \\
\hline 1 & $3+$ & $N G$ & 0 & $N G$ & $P$ \\
\hline 2 & $2+$ & $\mathrm{BHS}$ & 0 & ECOL BHS & $P$ \\
\hline 3 & $1+$ & $\mathrm{BHS}$ & 0 & STAU & B \\
\hline 4 & $3+$ & $N G$ & 0 & $N G$ & $\mathrm{P}$ \\
\hline 5 & $1+$ & BHS STAU & 0 & $N G$ & $P$ \\
\hline 6 & $3+$ & $N G$ & 0 & $N G$ & $P$ \\
\hline 7 & $1+$ & $\mathrm{BHS}$ & 0 & $\mathrm{BHS}$ & $B$ \\
\hline 8 & $3+$ & BHS AHS & 0 & $\mathrm{BHS}$ & $B$ \\
\hline 9 & $1+$ & $\mathrm{BHS}$ & $2+$ & $N G$ & P \\
\hline 10 & $3+$ & $\mathrm{BHS}$ & $3+$ & $N G$ & $P$ \\
\hline 11 & $1+$ & $N G$ & 0 & $N G$ & $B$ \\
\hline 12 & $1+$ & $\mathrm{BHS}$ & 0 & $N G$ & $P$ \\
\hline 13 & $3+$ & BHS STAU & 0 & $\mathrm{BHS}$ & $P$ \\
\hline 14 & $3+$ & $\mathrm{BHS}$ & $1+$ & $\mathrm{BHS}$ & $B$ \\
\hline 15 & $3+$ & $\mathrm{BHS}$ & 0 & $\mathrm{BHS}$ & $P$ \\
\hline 16 & $3+$ & $\mathrm{BHS}$ & 0 & BHS & $B$ \\
\hline 17 & $1+$ & $N G$ & 0 & $N G$ & $P$ \\
\hline 18 & $1+$ & STAU & 0 & $\mathrm{BHS}$ & $\mathrm{P}$ \\
\hline 19 & $3+$ & $N G$ & 0 & ECOL & $\mathrm{B}$ \\
\hline 20 & $2+$ & BHS NHS & 0 & $N G$ & $P$ \\
\hline 21 & $3+$ & AHS & 0 & $N G$ & $P$ \\
\hline 22 & $1+$ & BHS STFE & 0 & $N G$ & $P$ \\
\hline 23 & $2+$ & $\mathrm{HS}$ & 0 & $N G$ & $P$ \\
\hline 24 & $2+$ & $N G$ & $+1-$ & $N G$ & $\mathrm{P}$ \\
\hline
\end{tabular}




\section{Results}

Of the 1462 mares treated for acute endometritis, none showed clinical signs of distress, discomfort or vaginal discharge following treatments. Subsequent gynaecological examinations revealed no signs to suggest the presence of cervical or vaginal injury. No mares subsequently developed uterine infections with Pseudomonas spp. Four mares subsequently developed uterine infection with Aspergillus spp.,

Tab. 2: Mares treated with 3 daily intrauterine irrigations with $1 \mathrm{~g}$ ceftiofur sodium dissolved in $100 \mathrm{ml}$ sterile water for injection.

Stuten, die 3 mal täglich mit einer intrauterinen Spülung, bestehend aus $1 \mathrm{~g}$ Ceftiofur-Natrium, gelöst in $100 \mathrm{ml}$ sterilem Wasser pro inject. behandelt wurden.

\begin{tabular}{|c|c|c|c|c|c|}
\hline Mare & \multicolumn{2}{|c|}{$\begin{array}{c}\text { Initial } \\
\text { examination }\end{array}$} & \multicolumn{2}{c|}{$\begin{array}{c}\text { Follow-up } \\
\text { examination }\end{array}$} & Fert. \\
\hline pmns & $\begin{array}{c}\text { bacterial } \\
\text { growth }\end{array}$ & pmns & $\begin{array}{c}\text { bacterial } \\
\text { growth }\end{array}$ & \\
\hline 25 & $1+$ & BHS & 0 & NG & B \\
\hline 26 & $1+$ & NG & 0 & NG & P \\
\hline 27 & $1+$ & BHS & 0 & NG & $P$ \\
\hline 28 & $1+$ & NG & 0 & AHS & $P$ \\
\hline 29 & $1+$ & BHS & 0 & ECOL & B \\
\hline 30 & $3+$ & NG & 0 & BHS & $P$ \\
\hline 31 & $1+$ & NG & 0 & NG & $P$ \\
\hline 32 & $1+$ & NG & 0 & ECOL STFE & B \\
\hline 33 & $1+$ & NG & 0 & NG & $P$ \\
\hline 34 & $2+$ & NG & 0 & ECOL BHS & $P$ \\
\hline 35 & $2+$ & BHS & 0 & ECOL AHS & B \\
\hline 36 & $1+$ & ECOL & 0 & NG & $P$ \\
\hline 37 & $3+$ & STAU BHS & $+1-$ & NG & B \\
\hline 38 & $3+$ & BHS STFE & 0 & NG & $P$ \\
\hline 39 & $2+$ & AHS STAU & 0 & NG & B \\
\hline 40 & $1+$ & BHS & 0 & NG & $P$ \\
\hline
\end{tabular}

\section{Key to Tab. 1 and 2}

Fert = fertility status of the mare at the end of the breeding season.

$P=$ pregnant

$B=$ barren, i.e. not pregnant.

pmns = polymorphonuclear leucocytes.

$0=$ no pmns seen, $+/-=<5 \%, 1+=0.5-5 \%, 2+=5-30 \%$,

$3+=>30 \%$ pmns seen.

$N G=$ no aerobic growth of bacteria.

$\mathrm{BHS}=$ beta-haemolytic streptococci

AHS = alpha-haemolytic streptococci.

$\mathrm{ECOL}=$ Escherichia coli.

NHS = non-haemolytic streptococci.

STAU $=$ Staphylococcus aureus.

STFE $=$ Streptococcus faecalis two of which had been previously treated with repeated courses of penicillin, neomycin, polymixin and furaltadone mixture and two of which had been treated with prolonged ( 5 and 6 days respectively) courses of ceftiofur.

Of the 40 mares selected for more detailed study, successful resolution of acute endometritis occurred in 21 out of the $24(88 \%)$ mares that were treated with the penicillin, neomycin, polymixin and furaltadone mixture (Table 1) and 16 out of the $16(100 \%)$ mares that were treated with ceftiofur (Table 2).

Of the 40 mares selected for more detailed study, 17 out of the $24(71 \%)$ mares that were treated with the penicillin, neomycin, polymixin and furaltadone mixture (Table 1) and 10 out of the $16(63 \%)$ mares that were treated with ceftiofur (Table 2) ended the breeding season pregnant.

\section{Discussion}

Treatments for acute endometritis in mares must be both safe and efficacious. Irritant substances, such as strong iodine solutions and kerosene, and to a lesser extent tetracyclines, have been known to cause mares to show signs of abdominal pain, in some cases severe. Such treatments have been known to cause sufficient endometrial, cervical and vaginal inflammation to result in transluminal uterine and cervical adhesions and vaginal necrosis. These results revealed no evidence to suggest that the intrauterine instillation of either $3 \mathrm{~g}$ sodium benzy/penicillin, $1 \mathrm{~g}$ neomycin sulphate, 40,000 iu polymixin B sulphate and $600 \mathrm{mg}$ furaltadone hydrochloride or $1 \mathrm{~g}$ ceftiofur sodium, in $100 \mathrm{ml}$ sterile water daily for 3 days, was significantly irritant to the equine genitalia. Some antibiotic preparations which have been used for the treatment of acute endometritis in mares, notably intrauterine pessary preparations and, to a lesser extent procaine penicillin and ampicillin, leave insoluble or slowly absorbable residues in the uterus which can cause chronic endometritis which may predispose to the establishment of infection with more resistant bacteria such as Pseudomonas spp. Ceftiofur sodium is completely soluble in aqueous solution and none of the mares treated in this study developed uterine infections with this organism. In mares who have structural or functional genial abnormalities or who appear to have depressed uterine immune mechanisms, prolonged antibiotic treatment can predispose to the establishment of mycotic uterine infections. None of the 16 mares who were treated with ceftiofur sodium for 3 days subsequently developed mycotic endometritis but two mares who were treated daily for 5 and 6 days respectively, developed endometritis associated with Aspergillus spp. infection. Similarly, two of the mares treated extensively with the penicillin, neomycin, polymixin and furaltadone mixture also developed Aspergillus spp. endometritis. In the experience of Rossdale and Partners, this was an unusually high incidence of fungal infection, for reasons which are not clear. Nevertheless, there is no clear evidence to suggest that ceftiofur sodium presents an extra risk for producing mycotic endometritis, as compared with the penicillin, neomycin, polymixin and furaltadone mixture. 
The results show that ceftiofur sodium is successful in treating equine endometritis associated with the Gram positive and negative aerobic bacterial species that are most commonly isolated from endometrial swab samples (beta-haemolytic streptococci, Escherichia coli and Staphylococcus aureus). Although anaerobic bacterial cultures were not performed, the study published by Ricketts and Mackintosh (1987) suggests that $<65 \%$ of these cases of acute endometritis would have been associated with anaerobic bacteria, most commonly Bacteroides fragilis, either alone or synergistically with aerobic bacteria. As all cases showed satisfactory cytological resolution of endometritis, it must therefore be assumed that ceftiofur sodium is successful in treating equine endometritis associated with the anaerobic bacterial species that can be most commonly isolated from endometrial swab samples.

Although $63 \%$ of the 16 mares treated with ceftiofur sodium ended the breeding season pregnant, as compared with $71 \%$ of the 24 mares treated with the penicillin, neomycin, polymixin and furaltadone mixture, this difference is unlikely to be significant. In addition to the small size of the data set, some of the mares selected for treatment with ceftiofur sodium were particularly difficult cases, who had been previously treated with the penicillin, neomycin, polymixin and furaltadone mixture.

These results suggest that $1 \mathrm{~g}$ ceftiofur sodium dissolved in $100 \mathrm{ml}$ sterile water for injection, when instilled into the uterus of mares daily for three consecutive days is as safe and at least as efficacious in the treatment of acute endometritis as $3 \mathrm{~g}$ sodium benzy/penicillin, $1 \mathrm{~g}$ neomycin sulphate, 40,000 iu polymixin B sulphate and $600 \mathrm{mg}$ furaltadone hydrochloride dissolved in $100 \mathrm{ml}$ sterile water for injection, used similarly. If licensed for use in horses for the treatment of endometritis, ceftiofur would give veterinary surgeons a useful alternative therapeutic opportunity.

\section{References}

Burmudez, V., Sifontes, L., Navarro, N., Quintero, B., Moreno, J. and Bugos, M. (1995): Effects of intrauterine infusion of sodium ceftiofur on the endometrium of mares. Poster Exhibit. Proc. 41st Ann. Conv. Am. Ass. Equine Practnrs, 261-263.

Hughes, J.P. and Loy, R. G. (1975): The relation of infection to infertility in the mare and stallion. Equine Vet. J., 7, 155-.

Kenney, R.M., Bergman, R.V., Cooper, W. L. and Morse, G.W. (1975): Minimal contamination techniques for breeding mares: techniques and preliminary findings. Proc. 21st Ann. Conv. Am. Ass. Equine Practnrs., 327-.

Mackintosh, M.E. (1981): Bacteriological techniques in the diagnosis of equine genital infection. Vet. Record, 108, 52-55.
Peterson, F. B., McFeely, R. A. and David, J. S. E. (1969): Studies on the pathogenesis of endometritis in the mare. Proc. 15th Ann. Conv. Am. Ass. Equine Practnrs., 279-.

Powell, D. G., David, J.S. E. and Frank, C.J. (1978): Contagious equine metritis. The present situation and a revised code of practice for control. Vet. Record, 103, 399-402.

Ricketts, S.W. (1981): Bacteriological examinations of the mare's cervix: Techniques and interpretation of results. Vet. Record, 108, $46-51$.

Ricketts, S.W. (1987): Uterine abnormalites. In Current Therapy in Equine Medicine, 2nd Edit., Ed. N.E. Robinson, W. B. Saunders Co., 503.

Ricketts, S. W. (1995): The non-pregnant mare. In The Equine Manual, Ed. A. J. Higgins \& I. M. Wright, W. B. Saunders Co., 606-617.

Ricketts, S. W. and Mackintosh, M.E. (1987): Role of anaerobic bacteria in equine endometritis. J. Reprod. Fert. Suppl. 35, 343-351.

Ricketts, S. W. Young, A. and Medici, E. B. (1993): Uterine and clitoral cultures. In Equine Reproduction. Ed. A. O. McKinnon \& J. L. Voss. Lea \& Febiger. 234-245.

Rossdale, P. D. and Ricketts, S. W. (1980): Equine Studfarm Medicine. 2nd Edition. Bailliere Tindall. 53-111.

Wingfield Digby, N.J. (1978): The technique and clinical application of endometrial cytology in mares. Equine Vet. J., 10, 167-170.

Wingfield Digby, N.J. and Ricketts, S. W. (1982): Results of concurrent bacteriological and cytological examinations of the endometrium of mares in routine studfarm practice 1978-1981. J. Reprod. Fert. Suppl. 32, 181-185.

\section{Acknowledgements}

I thank Graham Hewitt of Upjohn Ltd. for supplies of Excenel for this trial and my colleagues Peter Rossdale, Nicholas Wingfield Digby, Andrew McGladdery, Sarah Stoneham, Deidre Carson, Simon Abbott and Euan Curnow for help with the selection and treatment of mares.

Sidney W. Ricketts,

Beaufort Cottage Stables

High Street

Newmarket, Suffolk CB8 8JS

England

Tel: 0044-1638-663150

Fax: 0044-1638-660157 